\title{
REBUDGETING: DAMPAK RATCHETING ANGGARAN TERHADAP PENCAPAIAN MUTU PENDIDIKAN PADA LEMBAGA PENDIDIKAN SE-WILAYAH KOTA MADIUN
}

\author{
Zuriah Apriliantin dan Y Anni Aryani \\ Magister Akuntansi Universitas Sebelas Maret Surakarta \\ zuriah apriliantin@yahoo.com
}

\begin{abstract}
ABSTRAK
Penelitian ini bertujuan untuk mengetahui pengaruh ratcheting anggaran terhadap pencapaian mutu pendidikan. Ratcheting anggaran diukur dengan cara menghitung persentase varian anggaran tahun 2012 dan tahun 2013 pada pos anggaran gaji, perlengkapan dan bahan pembelajaran, serta anggaran noninstruksional. Mutu pendidikan diukur melalui pencapaian hasil rata-rata nilai ujian akhir nasional (NUN). Penelitian ini menggunakan data sekunder dari lembaga pendidikan. Dari 151 lembaga pendidikan yang ada di Wilayah Kota Madiun, yang dapat digunakan untuk penelitian sebanyak 42 lembaga dengan metode penelitian untuk mengukur ratcheting anggaran menggunakan regresi berganda (multiple regression) sedangkan untuk menguji pengaruh ratcheting anggaran terhadap pencapaian mutu pendidikan menggunakan regresi sederhana (ordinary regression). Hasil penelitian menemukan bahwa Ratcheting anggaran berpengaruh negatif terhadap pencapaian mutu pendidikan, sehingga dapat disimpulkan bahwa belum tentu peningkatan ratcheting anggaran diikuti oleh peningkatan pencapaian mutu pendidikan.
\end{abstract}

Kata kunci: Ratcheting, Anggaran, Mutu Pendidikan, Madiun

\section{PENDAHULUAN}

Besarnya anggaran belanja dari pendapatan di suatu daerah dapat menyebabkan pemerintah setempat mengatur anggaran sedemikian rupa dengan menggunakan kelebihan anggaran tahun sebelumnya untuk menutupi defisit anggaran tahun berjalan dan bahkan dapat mengatur belanja pemerintah pada tahun mendatang. Pengaturan belanja demikian oleh Indjejikian dan Nanda (2002) disebut ratcheting anggaran. Mereka menjelaskan bahwa ratcheting adalah upaya dimana perusahaan memperbarui dan merevisi pencapaian target untuk mencerminkan kinerja masa lalu mereka, mempengaruhi insentif saat ini dan masa depan. Pendapat Lee dan Plummer (2007) menjelaskan bahwa dalam pengaturan pemerintah, ratcheting terjadi ketika tahun sebelumnya overspending (pengeluaran aktual melebihi anggaran) yang menyebabkan perubahan absolut lebih besar pada tahun ini dalam menganggarkan belanja.

Permasalahan yang dihadapi oleh pemerintah adalah bagaimana menganggarkan kembali (rebudgeting) belanja tahun berjalan dengan menggunakan kelebihan anggaran tahun lalu yang dimulai dari tahap perencanaan, monitoring/pengawasan, evaluasi, hingga umpan balik dari yang dihasilkan pemerintah setelah menerima dan membelanjakan sejumlah dana yang tertera di APBN/APBD yang telah mendapat persetujuan dari lembaga legislatif (DPR), termasuk di dalamnya anggaran pendidikan selain gaji pendidik dan biaya 
pendidikan kedinasan yang dialokasikan minimal 20\% dari Anggaran Pendapatan dan Belanja Negara (APBN) dan minimal 20\% dari Anggaran Pendapatan dan Belanja Daerah (UU nomor 20 Tahun 2003).

Anggaran pendidikan merupakan faktor yang tidak dapat dihindarkan dalam menyediakan komponen-komponen input pendidikan karena anggaran pendidikan merupakan salah satu komponen penting dalam penyelenggaraan pendidikan. Pendidikan merupakan suatu proses, oleh karena itu input yang bermutu akan menciptakan proses belajar mengajar yang bermutu dan membuat hasil belajar yang lebih baik dan bermutu pula jika didukung oleh sarana penunjang pendidikan yang memadai. Sementara realisasi anggaran pendidikan tersebut ternyata masih belum menyerap semua dana yang dianggarkan oleh pemerintah. Tingginya Silpa (Sisa Lebih Perhitungan Anggaran) membuktikan bahwa penyerapan anggaran pendidikan masih rendah. Cairns dan Soubeyran (2002), Lee dan Plummer (2007) menjelaskan bahwa ratcheting anggaran bagi pemerintah menyiratkan pertumbuhan asimetris dalam pengeluaran. Hotlhausen, Larckes, dan Sloan (1995) menyebutkan bahwa proses penganggaran adalah hal yang tipikal dari ratchet target, artinya besarnya anggaran meningkat pada tahuntahun disaat kinerja aktual tahun sebelumnya melebihi standar kinerja tahun berjalan tapi tidak menurun ketika kinerja sebenarnya tidak memenuhi standar.

\section{KAJIAN TEORI DAN PENGEMBANGAN HIPOTESIS}

"Ratcheting" didefinisikan sebagai upaya dimana perusahaan memperbarui dan merevisi pencapaian target untuk mencerminkan kinerja masa lalu mereka, mempengaruhi insentif saat ini dan masa depan (Indjejikian dan Nanda 2002). Ratcheting muncul dalam penelitian ekonomi yang berfokus pada dinamika insentif dalam hubungan antara prinsipal-agen sebagaimana dikemukakan oleh Milgrom dan Robert (1992); Laffont dan Tirole (1988) dalam Spencer dan Moorman (2008) yang menjelaskan bahwa kurangnya informasi tentang agen dapat menimbulkan "adverse selection". Prinsipal yang tidak tahu karakter agen mana yang berkinerja tinggi dan mana agen yang berkinerja rendah menyebabkan prinsipal tidak bersedia membuat kontrak selama lebih dari satu periode. Sementara agen mengantisipasinya dengan asumsi bahwa prinsipal akan menggunakan kinerja periode tahun berjalan untuk menentukan kinerja standar pada periode yang akan datang, sehingga agen relatif underperform terhadap tingkat kemampuan mereka.

Penelitian sebelumnya menjelaskan bahwa ratcheting dapat didefinisikan sebagai kecenderungan membuat perencanaan dengan menggunakan kinerja saat ini sebagai kriteria dalam menentukan tujuan masa depan. Hal ini menyebabkan adanya insentif yang dinamis di masa yang akan datang. Oleh karena itu pemberian imbalan yang lebih tinggi untuk kinerja saat ini harus mempertimbangkan target masa depan yang lebih ambisius (Weitzman 1980; Keren, Miller, dan Thornton 1983; Baron dan Besanko 1984; Darvish dan Tahana 1987). Hasil pendidikan, dalam hal ini adalah hasil ujian nasional merupakan indikator mutu pendidikan. Ada beberapa faktor yang mempengaruhi hasil pendidikan seperti yang dijelaskan oleh Bridge, Judd, dan Mocck (1979) yang menyatakan bahwa hasil pendidikan merupakan fungsi produksi dari proses pembelajaran yang efektif, kepemimpinan, peran serta guru, peran serta siswa, manajemen, organisasi, lingkungan fisik dan sumberdaya, kepuasan pelanggan 
sekolah, dukungan input dan fasilitas, dan budaya sekolah. Optimalisasi dari masing-masing komponen ini menentukan mutu sekolah sebagai satuan penyelenggara pendidikan.

Pada bagian ini peneliti ingin menyelidiki penerapan anggaran dan kinerja yang optimal di sektor publik yang mungkin berbeda dengan sektor privat. Sektor publik, khususnya lembaga pendidikan memerlukan anggaran untuk melaksanakan aktivitasnya, bahkan dianggarkan 20\% dari Anggaran Pendapatan dan Belanja Negara (APBN) dan minimal 20\% dari Anggaran Pendapatan dan Belanja Daerah (UU nomor 20 Tahun 2003). Anggaran pendidikan merupakan salah satu input sumberdaya yang sangat penting dalam pendidikan. Tanpa dukungan dana yang cukup akan sangat sulit mencapai mutu hasil pendidkan yang diharapkan. Anggaran pendidikan diperlukan untuk memfasilitasi pelaksanaan kebijakan dan program sekolah sebagai lembaga pendidikan yang bermutu. Dalam penelitian ini anggaran pendidikan dibedakan dalam 3 (tiga) kelompok yaitu anggaran untuk gaji dan honorarium, anggaran untuk pembelian perlengkapan dan bahan pembelajaran, serta anggaran untuk kebutuhan non-instruksional yaitu anggaran selain gaji, perlengkapan dan bahan pembelajaran. Anggaran tersebut digunakan untuk mencapai kinerja tertentu yang telah ditetapkan atau pencapaian kinerja tergantung dari besarnya anggaran yang disediakan.

Berdasarkan hasil penelitian terdahulu di sektor privat masih ada ketidakpastian tentang pengaruh ratcheting anggaran terhadap pencapaian target yang telah ditetapkan, bisa berpengaruh positif atau negatif, sedangkan di sektor publik, menurut hasil penelitian Ladd (1990) ratcheting anggaran berpengaruh positif terhadap pencapaian target. Oleh karena itu peneliti ingin menguji kembali pengaruh ratcheting anggaran melalui Rencana Kerja Anggaran Sekolah terhadap pencapai target yaitu mutu pendidikan, dalam hal ini mutu pendidikan dapat dilihat dari hasil pencapaian rata-rata nilai ujian akhir nasional pada lembaga pendidikan se-wilayah kota Madiun, sehingga dalam penelitian ini dapat dirumuskan hipotesis sebagai berikut:

H1 : Ratcheting anggaran (rebudgeting) berpengaruh terhadap mutu pendidikan.

\section{METODE PENELITIAN}

\section{A. Populasi, Sampel, dan Teknik Pengambilan Sampel}

1. Populasi Penelitian

Populasi dalam penelitian ini adalah lembaga pendidikan yaitu seluruh sekolah baik negeri maupun swasta yang berada di wilayah Kota Madiun. Adapun lembaga pendidikan di Wilayah Kota Madiun sebanyak 151 lembaga yang terdiri dari SD/MI sebanyak 82 lembaga, SMP/MTs sebanyak 24 lembaga, dan SMA/SMK/ MA sebanyak 45 lembaga.

\section{Sampel dan Sampling}

Teknik pengambilan sampel dalam penelitian ini yaitu memberikan peluang yang sama bagi anggota populasi untuk dipilih menjadi anggota sampel (probability sampling). Penentuan besarnya sampel berdasarkan informasi atau data yang berhasil peneliti dapatkan, pengambilan sampel dapat dilakukan dengan metode purposive sampling (sampel dengan kriteria tertentu), adapun kriterianya adalah sebagai berikut: 1) Sekolah 
(SD/MI, SMP/MTs, dan MA/SMK/MA) yang berada di wilayah Kota Madiun. 2) Sekolah (SD/MI, SMP/MTs, dan SMA/SMK/MA) yang dapat memberikan informasi tentang RKAS dan laporan realisasi penggunaan anggaran untuk tahun 2011/2012 dan tahun 2012/2013.

Kriteria tersebut digunakan karena ada anggota populasi yang tidak dapat dijadikan sampel disebabkan tidak adanya data yang dapat digunakan sebagai sumber penelitian yaitu Rencana Kegiatan dan Anggaran Sekolah (RKAS) tahun pelajaran 2011/2012 dan 2012/2013 dan laporan (realisasi) penggunaan dana anggaran tahun pelajaran 2011/2012. Berdasarkan data yang berhasil peneliti peroleh, dari populasi sebanyak 151 lembaga pendidikan yang berada di wilayah kota Madiun, peneliti dapat mengambil sampel sebanyak 42 lembaga yang terdiri dari jenjang pendidikan SD/MI sebanyak 26 lembaga, jenjang SMP/MTs sebanyak 6 lembaga, dan pada jenjang SMA/SMK/MA sebanyak 10 lembaga.

\section{B. Teknik Pengumpulan Data}

Teknik pengumpulan data yang dipilih oleh peneliti adalah teknik dokumentasi. Teknik ini dipilih sebab data yang hendak diperoleh merupakan data sekunder yang bersumber dari sekolah sampel (SD/MI sebanyak 26 sekolah, SMP/MTs sebanyak 6 sekolah, dan SMA/SMK/MA sebanyak 10 sekolah) baik yang tersedia di Dikbudmudora Kota Madiun maupun yang diperoleh langsung dari sekolah sampel. Data yang diperlukan berupa Rencana Kegiatan dan Anggaran Sekolah (RKAS) tahun pelajaran 2011/2012 dan 2012/2013 dan laporan (realisasi) penggunaan dana anggaran tahun pelajaran 2011/2012, untuk mengetahui adanya ratcheting anggaran di lembaga pendidikan dan data rata-rata nilai ujian akhir nasional (NUN) tahun 2012/2013 untuk mengetahui tingkat mutu pendidikan (mutu hasil belajar) yang berhasil dicapai oleh lembaga pendidikan yang bersangkutan.

\section{Definisi Operasional dan Pengukuran Variabel}

1. Variabel Bebas atau Independent Variable (X)

Variabel Independent dalam penelitian ini adalah ratcheting anggaran. Ratcheting anggaran didefinisikan sebagai kecenderungan membuat perencanaan dengan menggunakan kinerja saat ini sebagai kriteria dalam menentukan tujuan masa depan (Weitzman 1980; Keren, Miller, dan Thornton 1983; Baron dan Besanko 1984; Darvish dan Tahana 1987), sedangkan Indjejikian dan Nanda (2002) mendefinisikan ratcheting anggaran sebagai upaya dimana perusahaan memperbarui dan merevisi pencapaian target untuk mencerminkan kinerja masa lalu mereka, mempengaruhi insentif saat ini dan masa depan.

\section{a. Ratcheting Anggaran.}

Ratcheting anggaran dihitung dengan cara mencari persentase varian antara anggaran pada tahun 2012 dengan anggaran pada tahun 2013. Penelitian ini menggunakan pos anggaran Gaji, beban perlengkapan dan bahan pembelajaran serta anggaran non-instruksional sebagai variabel yang mengalami penyesuaian. 


$$
\begin{aligned}
\left(B_{t}-B_{t-1}\right) / B_{t-1}= & \alpha_{0} / B_{t-1}+\alpha_{1}\left(A_{t-1}-B_{t-1}\right) / B_{t-1}+\alpha_{2} \Delta \mathrm{Gaji}+\alpha_{3} \Delta \mathrm{PBP}+ \\
& \alpha_{4} \Delta \mathrm{NISTR}+\alpha_{5}\left(\text { ARev }_{t-1}-\text { BRev }\right)+\varepsilon \ldots \ldots \ldots \ldots \ldots \ldots \ldots \ldots \ldots \ldots \ldots
\end{aligned}
$$

Keterangan:

$B_{t} \quad$ : pengeluaran anggaran pada tahun $\mathrm{t}$

$B_{t-1} \quad$ : pengeluaran anggaran pada tahun t-1(sebagai kontrol)

$A_{t-1} \quad$ : pengeluaran yang sebenarnya pada tahun $\mathrm{t}-1$

$\Delta$ Gaji $\quad$ : persentase perubahan gaji dari tahun $\mathrm{t}-1$ ke tahun $\mathrm{t}$

$\triangle$ PBP : persentase perubahan beban perlengkapan dan bahan pembelajaran dari tahun $\mathrm{t}-1$ ke tahun $\mathrm{t}$

$\triangle$ NISTR : persentase perubahan beban non instruksional dari tahun t-1 ke tahun $\mathrm{t}$

ARev $v_{\mathrm{t}-1} \quad$ : penerimaan sebenarnya pada tahun $\mathrm{t}-1$

$B R e v_{\mathrm{t}-1}$ : penerimaan anggaran pada tahun $\mathrm{t}-1$

$\varepsilon \quad$ : variabel pengganggu

2. Variabel Terikat atau Dependent Variable (Y)

Variabel terikat (dependent variable) yang digunakan dalam penelitian ini adalah mutu pendidikan (mutu hasil belajar). Mutu pendidikan lebih khusus dapat diartikan sebagai prestasi akademik yang berhasil diperoleh siswa setelah menyelesaikan masa belajarnya (lulus) yang dinyatakan dalam bentuk nilai ujian atau nilai hasil belajar. Evaluasi belajar yang digunakan adalah hasil nilai rata-rata ujian akhir nasional (NUN). Indikator pencapaian mutu pendidikan dapat diukur melalui hasil rata-rata nilai ujian akhir nasional (NUN) yang dapat dirumuskan sebagai

$$
\bar{X} N U N \text { siswa }=\frac{\sum N U N}{n}
$$

Keterangan :

$\overline{\mathrm{X}}$ NUN siswa $\quad$ : Rata-rata Nilai Ujian Nasional per siswa.

NUN : Nilai ujian nasional yang dicapai siswa.

$\mathrm{n} \quad$ : Jumlah mata pelajaran yang diujikan secara nasional

(SD: 3 mata pelajaran, SMP: 4 mata pelajaran, SMA: 6 mata pelajaran, dan SMK: 4 mata pelajaran).

Nilai rata-rata ujian akhir nasional (NUN) per siswa yang berhasil dicapai oleh sekolah dapat dihitung melalui rumus berikut:

$$
\bar{X} \text { NUN Sekolah }=\frac{\sum \bar{x} \text { NUNsiswa }}{n}
$$

Keterangan

$\overline{\mathrm{X}}$ NUN Sekolah $\quad$ : Rata-rata Nilai Ujian Nasional per sekolah.

$\mathrm{n} \quad$ : Jumlah siswa yang mengikuti ujian nasional pada sekolah yang bersangkutan.

\section{HASIL PENELITIAN DAN PEMBAHASAN}

Pengujian hipotesis dilakukan dengan tujuan untuk menguji ada tidaknya pengaruh variabel independen ( ratchet) terhadap variabel dependen (mutu pendidikan/mutu hasil belajar). Berikut adalah hasil dari pengujian regresi linier 
sederhana (ordinary regression) untuk pengaruh ratcheting anggaran terhadap pencapaian mutu pendidikan melalui program software SPSS 16.00.

1. Uji Koefisien Regresi dengan Uji t

Uji koefisien regresi dengan uji t ini digunakan untuk mengetahui apakah variabel independen (ratchet) berpengaruh secara signifikan terhadap variabel dependen (mutu pendidikan). Signifikan berarti pengaruh yang terjadi dapat berlaku untuk populasi (dapat digeneralisasikan).

Tabel 1

Uji t

\begin{tabular}{|c|c|c|c|c|c|c|}
\hline \multirow[b]{2}{*}{ Model } & & \multicolumn{3}{|r|}{$\begin{array}{l}\text { Standardized } \\
\text { Coefficients }\end{array}$} & \multirow[b]{2}{*}{$\mathrm{t}$} & \multirow[b]{2}{*}{ Sig. } \\
\hline & & B & Std. Error & Beta & & \\
\hline \multirow[t]{2}{*}{1} & (Constant) & 9.411 & .491 & & 19.160 & .000 \\
\hline & \% RATCHET & -.045 & .014 & -.463 & -3.300 & .002 \\
\hline
\end{tabular}

a. Dependent Variable: MUTU PENDIDIKAN

Dari hasil analisis regresi di atas dapat diketahui bahwa $\mathrm{p}=0,002$ dan $0,002<0,05$ sehingga $\mathrm{H}_{0}$ ditolak. Koefisien sebesar negatif 0.045 menunjukkan bahwa variabel RATCHET mempunyai pengaruh negatif terhadap variabel MUTU PENDIDIKAN. Hal ini dapat diartikan bahwa jika ratcheting anggaran meningkat maka hasil pencapaian mutu pendidikan (mutu hasil belajar) justru menurun.

2. Hasil Uji Koefisien Determinasi dengan Uji F

Pengujian hipotesa dengan menggunakan uji $\mathrm{F}$ atau disebut Analysis of Variance (ANOVA) bisa dilakukan dengan melihat tingkat signifikansi dari hasil pengujian. Pengujian dengan tingkat signifikansi dilakukan dengan ketentuan yaitu apabila hasil signifikansi pada tabel ANOVA < 0,05, maka $\mathrm{H}_{0}$ ditolak dan apabila ANOVA > 0,05, maka $\mathrm{H}_{0}$ diterima. Hasil uji F dengan program SPSS versi 16.00 tampak pada Tabel 10 yang menunjukkan bahwa nilai $\mathrm{p}$ sebesar 0,002 dan 0,002<0,05, hal ini menunjukkan bahwa $\mathrm{H}_{0}$ ditolak. Berdasarkan hasil uji tersebut dapat diartikan bahwa ratcheting anggaran berpengaruh terhadap mutu pendidikan.

\section{Tabel 2}

Uji F

\begin{tabular}{|c|c|c|c|c|c|c|}
\hline Model & & Sum of Squares & Df & Mean Square & $\mathrm{F}$ & Sig. \\
\hline \multirow[t]{3}{*}{1} & Regression & 6.585 & 1 & 6.585 & 10.892 & $.002^{\mathrm{a}}$ \\
\hline & Residual & 24.184 & 40 & .605 & & \\
\hline & Total & 30.769 & 41 & & & \\
\hline
\end{tabular}

a. Predictors: (Constant), \%RATCHET

b. Dependent Variable: MUTU PENDIDIKAN 
3. Hasil Uji Koefisien Determinasi dengan Uji R

Pengujian ini menunjukkan koefisien determinasi yang berfungsi untuk mengetahui besarnya persentase variabel dependen dapat diprediksi dengan variabel independen.

\section{Tabel 3}

Uji R

\begin{tabular}{llrcrrr}
\multicolumn{8}{c}{ Model Summary $^{\mathbf{b}}$} \\
\hline Model & $\mathrm{R}$ & R Square & $\begin{array}{c}\text { Adjusted R } \\
\text { Square }\end{array}$ & $\begin{array}{c}\text { Std. Error of the } \\
\text { Estimate }\end{array}$ & Durbin-Watson \\
\hline 1 & $.463^{\mathrm{a}}$ & .214 & & .194 & .77756 & 2.016 \\
\hline
\end{tabular}

a. Predictors: (Constant), \%RATCHET

b. Dependent Variable: MUTU PENDIDIKAN

Dari data yang tampak pada Tabel 11 diperoleh nilai $\mathrm{R}$ Square sebesar 0,214 atau 21,40\%. Angka ini menunjukkan bahwa sebesar $21,40 \%$ variabel mutu pendidikan dapat dijelaskan dengan menggunakan variabel ratchet, sedangkan sisanya $(100-21,40=78,60)$ dijelaskan oleh variabel-variabel yang lain. Besarnya SEE (Std. Error of the Estimate) adalah 0,777, jika dibandingkan dengan nilai standar deviasi pada Tabel 4 yaitu sebesar 0,866 maka nilai SEE lebih kecil $(0,777<0,866)$, artinya variabel ratchet baik untuk dijadikan prediktor bagi variabel mutu pendidikan.

Hipotesis penelitian ini adalah ratcheting anggaran berpengaruh terhadap mutu pendidikan. Hasil penelitian membuktikan adanya pengaruh langsung ratcheting anggaran terhadap mutu pendidikan yang ditunjukkan oleh nilai koefisien variabel ratchet negatif terhadap mutu pendidikan dengan tingkat signifikansi 0.002 . Hal ini disebabkan ratcheting anggaran dalam penelitian ini terbatas pada pos anggaran gaji, pembelian perlengkapan dan bahan pembelajaran (PBP), dan anggaran untuk pembelanjaan non-instruksional (anggaran selain gaji dan PBP), tidak diperhitungkan dalam penelitian ini adalah biaya-biaya yang tidak dianggarkan dalam RKAS seperti biaya yang dibelanjakan siswa untuk kepentingan sendiri, biaya pajak, biaya penyusutan/depresiasi atas nilai aset tetap, karena sulit diprediksi dan tidak tersedianya data yang diperoleh peneliti. Hasil pengukuran ratcheting anggaran menunjukkan bahwa penyesuaian anggaran lebih besar dilakukan di pos anggaran gaji yang ditunjukkan oleh besarnya koefisien positif yaitu sebesar 0,372, sedangkan ratcheting anggaran untuk pembelian perlengkapan (bahan habis pakai) dan bahan pembelajaran ditunjukkan oleh koefisien negatif sebesar 0,006 yang berdasarkan hasil pengujian di atas tidak signifikan artinya penurunan anggaran di pos PBP akan meningkatkan persentase ratcheting anggaran yang digunakan untuk pembelanjaan pos anggaran lain yang tidak berpengaruh langsung terhadap pencapaian mutu pendidikan dan sebaliknya, peningkatan anggaran di pos PBP akan menurunkan persentase ratcheting anggaran yang pengaruhnya tidak signifikan.

Pengaruh negatif ratcheting anggaran terhadap mutu pendidikan disebabkan pula oleh adanya ratcheting anggaran yang dilakukan oleh sekolah tertentu dengan persentase yang lebih rendah tetapi mampu mencapai rata-rata nilai ujian akhir nasional yang lebih tinggi dari sekolah yang melakukan 
ratcheting anggaran dengan persentase yang tinggi atau bisa dikatakan bahwa belum tentu ratcheting anggaran yang tinggi akan menghasilkan rata-rata nilai ujian nasional yang tinggi pula. Misal, SMKN 2 Madiun melakukan ratcheting anggaran sebesar $32,13 \%$ berhasil mencapai rata-rata nilai ujian akhir nasional sebesar 8,96 per siswa, sedangkan SMPN 14 Madiun melakukan ratcheting anggaran sebesar $56,81 \%$ tetapi rata-rata hasil ujian akhir yang dicapai sebesar 5,16 per siswa. Faktor- faktor lain yang tidak dijelaskan dalam penelitian ini yang kemungkinan dapat mempengaruhi pencapaian rata-rata hasil ujian nasional, misal mutu input siswa, mutu proses belajar mengajar, minat dan bakat siswa, motivasi belajar siswa, sarana belajar siswa di rumah dan lain-lain. Hasil penelitian ini mendukung dan konsisten dengan penelitian yang dilakukan oleh Syamsudin (2009) yang menyimpulkan bahwa biaya pendidikan berpengaruh negatif terhadap mutu hasil belajar melalui mutu proses belajar mengajar.

Hasil penelitian ini bertentangan dengan penelitian yang dilakukan oleh Ladd (1999) yang membuktikan bahwa penambahan anggaran untuk insentif gaji guru dapat meningkatkan hasil skor tes siswanya, bertentangan pula dengan hasil riset Fatah (1998) dalam Syamsudin (2009) yang menyimpulkan bahwa biaya pendidikan memberikan kontribusi positif yang signifikan terhadap upaya peningkatan mutu pendidikan dan bertentangan dengan hasil penelitian yang dilakukan oleh Lee dan Plummer (2007) yang menjelaskan bahwa ratcheting anggaran yang terjadi di sektor publik lebih banyak dilakukan pada pos anggaran non-instruksional yaitu administrasi, bimbingan dan konseling dan layanan sosial, sedangkan dalam penelitian ini ratcheting anggaran lebih banyak terjadi di pos anggaran instruksional yaitu gaji, upah dan honorarium yang ditunjukkan oleh besarnya koefisien positif sebesar 0,372 sedangkan untuk pos anggaran non instruksional besarnya koefisien 0,171 .

\section{KESIMPULAN}

Berdasarkan penelitian dan pembahasan tentang pengaruh ratcheting anggaran terhadap pencapaian mutu pendidikan, maka dapat ditarik suatu kesimpulan bahwa ratcheting anggaran berpengaruh negatif terhadap pencapaian mutu pendidikan yang menunjukkan bahwa belum tentu ratcheting anggaran yang tinggi akan menghasilkan rata-rata nilai ujian nasional yang tinggi dan sebaliknya ratcheting anggaran yang rendah akan menghasilkan rata-rata nilai ujian nasional yang rendah pula.

Adapun saran yang dapat diberikan kepada peneliti berikutnya berdasarkan hasil penelitian yang telah dilakukan adalah sebagai berikut:

1. Menggunakan tahun anggaran yang panjang (time series) sehingga dapat dilihat pengaruhnya dari satu periode pengamatan ke periode pengamatan lainnya.

2. Menambah variabel penelitian yaitu biaya pajak, biaya penyusutan, dan biaya layanan sosial.

3. Memasukkan faktor-faktor yang berhubungan dengan pencapaian mutu pendidikan seperti mutu input siswa, mutu proses belajar dan mengajar, minat dan bakat siswa, motivasi belajar siswa, sarana belajar siswa di rumah ke dalam penelitian. 
DAFTAR PUSTAKA

Ahn, T. S. dan Y. S. Choi. 2009. Information Asymmetry and Ratchet Effect. Working Paper. Seoul National University.

Baron, D., dan D. Besanko. 1984. Regulation and information in continuing relationship. Information Economics and Policy: 267-302.

Bridge, R.G., Judd, C.M. \& Mocck, P.R. (1979). The Determinants of Educational Outcomes. Massachusetts: Balinger Publishing Company.

Burgess, S. dan Marisa, R. 2003. The Role of Incentives in The Public Sector: Issues and Evidence. Working Paper No. 03/071. University of Bristol

Chow C. W., J. C. Cooper, dan K. Haddad. 1991. The Effects of Pay Schemes and Ratchet on Budgetary Slack and Performance: A multi-period experiment. Accounting Organizations and Society 16(1): 47-60.

Darvish, T., dan N. Tahana. 1987. The ratchet principal: A diagrammatic interpretation. Journal of Comparative Economics: 245-249.

Ettredge, M. L., J. C. Bedard, dan K. M. Johnstone. 2007. Empirical Test of Audit Budget Dinamics. Working paper. University of Kansas.

Fatah, Nanang. 1998. Studi Tentang Pembiayaan Pendidikan Sekolah Dasar. Remaja Kodya Karya. Bandung: 136-158

Gersbach, Hans, dan A. Glazer. 2004. High Compensation Creates a Ratchet Effect. IZA Discussion Paper, University of California.

Ghozali. 2006. Aplikasi Analisis Multivariate dengan SPSS. Undip. Semarang

Holthausen, R. W., D. F. Larcker, dan R. Sloan. G. 1995. Annual Bonus Schemes and the Manipulation of Earnings. Journal of Accounting and Economics, 19, 29-74.

Indjejikian R. J., dan D. Nanda. 2002. Executive Target Bonuses and What They Imply About Performance Standards. The Accounting Review 77(4): 793819.

Keren, M., J. Miller, dan J. Thornton. 1983. The Ratchet: A Dynamic Managerial Incentive Model of the Soviet Enterprise. Journal of Comparative Economics: 347-367.

Kyle, R.M.J. (1985). Reaching for excellence. Washington U.S: Government Printing Office.

Lee, T. M., E. Plummer, dan Elizabeth. 2007. Budget Adjustment in Response to Spending Variances: Evidence of Ratchet of Local Government Expenditure. Journal of Management Accounting Research; 19, pp.137167

Ladd, H. F. 1999. “The Dallas School Accountability and Incentive Program: An evaluation of its impacts on student outcomes", Economics of Education Review, 18(1), pp.1-16.

Milgrom, P., dan J. Roberts. 1992. Economics, Organizations and Management. Englwood Cliffs, NJ: Prentice Hall.

Policy Brief. 2005. Public Sector Modernisation: Modernising Accountability and Control. Organisation for Economic Co-operation and Development. Observer.

Peraturan Pemerintah Republik Indonesia Nomor 19. 2005. Standar Nasional Pendidikan 
Syamsudin, 2009, Pengaruh Biaya Pendidikan Terhadap Mutu Hasil Belajar Melalui Mutu Proses Belajar Mengajar Pada Sekolah Menengah Pertama di Kabupaten Asahan. Universitas Sumatera Utara. Medan.

Spencer, Fredrika J., dan Moorman, C. 2008. Firm Innovation and the Ratchet Effect: How Firms Trade Off Value Creation in Financial and Product Markets. Marketing Science Institute. Working Paper Series, Cambridge.

Undang-Undang Republik Indonesia Nomor 20 Tahun 2003 Tentang Sistem Pendidikan Nasional

Weitzman, M.L. 1980. The "ratchet principle" and Performance Incentives. The Bell Journal of Economics 11 (1): 302-308.

Yayuk Harumiati dan Payamta : Pengaruh Karakteristik Pemerintah Daerah Dan Temuan ... 